characterized by an accommodationist regime with the elements of cooperation. An example of this is agreements on the introduction of chaplaincy in the army, prisons, hospitals, signed by governmental structures with various churches. In addition, the government of Ukraine indirectly supports the spiritual and charitable activities of religious organizations, providing them with a favorable tax regime and reducing the cost of utilities.

However, these new church-state relations from time to time raise discussions in Ukrainian society and objections by some political and public figures about the expediency of the church's involvement in public life and its partnerships with government in various social spheres. Some of them are appealing to Article 35 (3) of the Constitution of Ukraine, promoting the restoration of the model of absolute separation between state and church similar to the one built by the totalitarian Soviet regime. It ignores the multifaceted approaches to building church-state relations that are used in developed democratic countries of Europe, where in addition to the separation model, cooperative forms of relations are much more commonly used.

The contradiction that exists between the provisions of the Constitution of Ukraine and the new type of relations, enshrined in the legislation and bilateral agreements between governmental structures and religious organizations, leads to legal uncertainty and creates the basis for social contradictions, misunderstandings, attempts to degrade modern church-state relations in Ukraine to the Soviet model.

This article argues that the Parliament of Ukraine has to extend Article 35 of the Constitution of Ukraine on church-state separation by additional provisions on the possibility of church to participate in public life and interact with state on a partnership basis in order to bring the Constitution into line with the modern state-church relations in Ukraine, which has already been implemented at a practical level.

Key words: church-state relations, church-state interaction, freedom of religion, church-state separation.

DOI: $10.36695 / 2219-5521.3 .2019 .14$

УДК 342.553(477)

\title{
М.Є. ГАЙДАР
}

Марія Єгорівна Гайдар, аспірант Інституту держави і права ім. В.М. Корецького НАН Украӥни* ORCID: 0000-0003-3498-3642

\section{ДО ПИТАННЯ ПОНЯТТЯ ОБ’ЄДНАНОЇ ТЕРИТОРІАЛЬНОÏ ГРОМАДИ В УКРАЇН}

Постановка проблеми. Конституційно-правова модернізація, що відбувається в нашій державі, спрямована на реформування системи місцевого самоврядування, на закріплення статусу територіальних громад основним суб'єктом місцевої демократії. Конституцією України визнається та гарантується місцеве самоврядування. Місцеве самоврядування визнається правом територіальної громади - жителів села чи добровільного об'єднання у сільську громаду жителів кількох сіл, селища та міста - самостійно вирішувати питання місцевого значення в межах Конституції і законів України (ст. 140). Неможливо не погодитись із твердженням М.О. Баймуратова стосовно того, що роль територіальних громад «особливо яскраво проявляється в умовах децентралізації публічної влади, коли територіальні громади як первинні суб'єкти місцевого самоврядування починають грати, з одного боку, конституюючу роль у становленні феномена локальної демократії, а з іншого - інституційну роль як найважливіший елемент громадянського суспільства» 1.

Аналіз останніх досліджень і публікацій. Питанням об’єднання територіальних громад присвячували свої наукові праці вітчизняні науковці та практики, зокрема М.О. Баймуратов, О.В. Батанов, О.В. Голинська, Ю.М. Ковальчук, І.Ф. Коломієць, Л. Муркович, Е.Т. Мустафаєва, О.В. Ольшанський, А.О. Пелехатий, А.В. Переверзєва, О.Я. Рогач, П.О. Саєнко, Н.Я. Спасів та ін. Водночас, не применшуючи наукових здобутків досліджень проблематики об'єднання територіальних громад, слід зазначити, що при цьому виникає низка питань, пов'язаних із конституційним регулюванням процесу об'єднання територіальних громад в Україні. Зокрема, донині законодавцем не запропоновано визначення об'єднаних територіальних громад, а вчені, які розглядають ОТГ, здебільшого фокусуються на висвітленні окремих ключових проблемних аспектів їх утворення та діяльності.

Формулювання мети статті. Враховуючи наведене вище, мета цієї статті полягає у науковому осмисленні здобутків вчених із дослідження поняття об'єднаної територіальної громади в Україні, а також формулювання авторського визначення ОТГ.

Виклад основного матеріалу. У Концепції реформування місцевого самоврядування та територіальної організації влади в Україні слушно зазначається про фактичне здійснення розвитку місцевого самоврядування на рівні територіальних громад міст обласного значення, позаяк здебільшого територіальні громади внаслідок їх надмірної подрібненості та надзвичайно слабкої матеріально-фінансової бази продемонстрували неспроможність виконувати всі повноваження органів місцевого самоврядування. Одним із завдань першого етапу реалізації Концепції було визначено створення законодавчої основи для реалізації права територіальних громад на добровільне об'єднання². У контексті зазначеного особливо актуальним вбачається тверджен-

(C) М.є. Гайдар, 2019

* Maria Gaidar, postgraduate student of V.M. Koretsky Institute of State and Law of the NAS of Ukraine 
ня М.О. Баймуратова стосовно того, що становлення й розвиток правової демократичної державності об’єктивно зумовлює зростання ролі та значення колективних суб'єктів права, які:

- виникають та функціонують на території держави;

- відповідно до ії Конституції та чинного законодавства;

- набуваючи і формуючи власний правовий статус;

- реалізуючи телеологічні домінанти щодо їх існування та функціонування;

- для задоволення власних інтересів суб'єктів, що становлять такий колектив, а також для задоволення групових і колективних інтересів всіх членів такого колективу ${ }^{2}$ Дослідник відносить до таких колективних суб' єктів права громади, проте наведені вище ознаки повною мірою характеризують і об'єднання територіальних громад.

Термін «об’єднання територіальних громад» фігурує у більшості нормативно-правових актів, які були прийняті у зв'язку із запровадженням реформи децентралізації, однак ані законодавчого, ані єдиного доктринального підходу до визначення терміну «об'єднана територіальна громада» досі не вироблено. Зокрема, на цю проблему звертала увагу Н.Я. Спасів, акцентуючи на тому, що «наукові публікації за даною проблематикою обмежуються роз'ясненням положень законодавства та відповідними коментарями» ${ }^{4}$. Втім, останнім часом вітчизняними дослідниками вже почали проводитися відповідні наукові пошуки до з'ясування сутності ОТГ.

Так, А.В. Переверзєва розглядає ОТГ як систему, яка складається з низки взаємопов'язаних елементів, таких як людські, земельні, капітальні ресурси 5 . При цьому сам процес утворення ОТГ визначається дослідницею як засіб реалізації загальнодержавної політики децентралізації5. Не заперечуючи поглядів дослідниці, зауважимо, що наведене визначення потребує удосконалення, оскільки не надає уявлення про повний перелік елементів, з низки яких, згідно із позицією автора, власне складається ОТГ. Крім того, наведене визначення, на наш погляд, не розкриває сутності та змістовних характеристик ОТГ.

Крім того, розгляд утворення ОТГ виключно як засобу реалізації політики децентралізації призводить до істотного звуження змісту цього процесу, позаяк утворення ОТГ слід розглядати як право суміжних територіальних громад сіл, селищ, міст добровільно, із дотриманням принципів та порядку, визначених чинним законодавством, за власним бажанням утворювати об'єднану територіальну громаду або приєднуватись до вже утворених ОТГ. Зокрема, законодавчо визначеними принципами добровільного об'єднання територіальних громад виступають:

- конституційність і законність;

- добровільність;

- економічна ефективність;

- державна підтримка;

- повсюдність місцевого самоврядування;

- прозорість і відкритість; мад) $)^{6}$.

- відповідальність (п.п. 1-7 ч. 1 ст. 2 Закону України «Про добровільне об’єднання територіальних гро-

П.О. Саєнко, досліджуючи ОТГ, зазначає, що «об’єднання територіальних громад є запорукою переходу місцевого самоврядування на якісно новий рівень»; при цьому процес добровільного об'єднання територіальних громад розглядається як один із основних інструментів стимулювання їх розвитку․ Вбачається, що такий підхід потребує подальшої деталізації та конкретизації, зокрема в аспекті висвітлення сутності ОТГ, акцентування уваги на основних умовах добровільного об'єднання територіальних громад. Дослідження процесу об'єднання територіальних громад як «інструменту» також, на наш погляд, звужує його зміст $\mathrm{i}$ відображає лише одну з його сторін, що не дає змоги сформувати об'єктивне уявлення щодо даного процесу.

Відповідно до профільного Закону територіальні громади можуть реалізовувати своє право на об'єднання у разі дотримання таких умов:

1) неможливість існування у складі ОТГ іншої територіальної громади, яка має свій представницький орган місцевого самоврядування;

2) нерозривність території ОТГ; визначення меж ОТГ по зовнішніх межах юрисдикції рад територіальних громад, що об'єдналися;

3) територіальне розташування ОТГ в межах Автономної Республіки Крим або однієї області;

4) врахування історичних, природних, етнічних, культурних та інших чинників, що впливають на соціально-економічний розвиток ОТГ при прийнятті рішень щодо добровільного об'єднання територіальних громад;

5) гарантування рівня якості та доступності публічних послуг, що надаються в ОТГ, не можуть бути нижче, ніж до такого об'єднання.

Заслуговує на увагу визначення І.В. Козюри, який доходить висновку, що «об’єднання територіальних громад означає соціально-політичне територіальне утворення, що одночасно виступає територіальною спільністю людей - суб'єктів місцевого самоврядування і низовою одиницею в системі адміністративно-

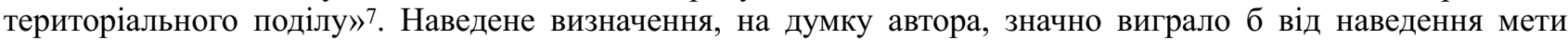
об'єднання територіальних громад, а також зазначення основних суб'єктів добровільного об'єднання територіальних громад, якими є суміжні територіальні громади сіл, селищ, міст (ч. 1 ст. 3 Закону України «Про добровільне об'єднання територіальних громад»). 
У свою чергу, Ю.М. Ковальчук стверджує, що при дослідженні поняття ОТГ слід зосереджуватись саме на понятті «територіальна громада», оскільки воно є похідним від поняття «територіальна громада». При цьому дослідник пропонує власне поняття ОТГ, яке визначає як «створене згідно із законом добровільне об’єднання територіальних громад сіл, селищ, міст, яке є первинною (базовою) одиницею в системі адміністративно-територіального устрою, та спроможне самостійно або через органи місцевого самоврядування вирішувати питання місцевого значення» 8 . Не піддаючи науковій критиці авторську позицію, слід зазначити, що, можливо, з погляду формальної логіки було б не зовсім коректно використовувати, з одного боку, словосполучення «об'єднана територіальна громада» в якості терміна, а з іншого - словосполучення «об'єднання територіальних громад» для його розкриття.

О. Кириленко зазначає, що об'єднання територіальних громад є «важливим елементом реформи місцевого самоврядування». При цьому науковець слушно стверджує, що основною метою зазначеного процесу $є$ формування спроможного базового елементу місцевого самоврядування - громади 9 . При цьому слід підкреслити, що держава підтримує право територіальних громад на об'єднання, надаючи підтримку добровільному об'єднанню територіальних громад або, відповідно, приєднанню до ОТГ, яка згідно із Законом України «Про добровільне об'єднання територіальних громад» здійснюється у таких формах:

1) забезпечення здійснення інформаційно-просвітницької, організаційної підтримки Радою міністрів Автономної Республіки Крим, а також місцевими державними адміністраціями (ч. 2 ст. 9);

2) забезпечення здійснення методичної підтримки, а також визначення обсягів та форми підтримки центральним органом виконавчої влади, що забезпечує формування та реалізує державну політику у сфері територіальної організації влади, адміністративно-територіального устрою, розвитку місцевого самоврядування (ч. 3 ст. 9);

3) забезпечення здійснення фінансової підтримки державою шляхом надання коштів у вигляді субвенцій на формування відповідної інфраструктури згідно з планом соціально-економічного розвитку такої територіальної громади (ч. 1 ст. 10).

О.В. Голинська стверджує, що «об’єднання територіальних громад є запорукою переходу місцевого самоврядування на якісно новий рівень», причому «децентралізація влади, що втілюється у передачі владних повноважень та ресурсів для їх забезпечення розглядається сьогодні через призму процесу добровільного об'єднання територіальних громад. Це об'єднання, своєю чергою, слід розглядати у контексті не лише ресурсних обмежень, а й поштовху цивілізаційного вибору» ${ }^{10}$. Вважаємо, що в даному випадку, все ж таки, було б зарано говорити про «поштовх цивілізаційного вибору», оскільки на практиці реалізація права на об'єднання територіальних громад зазнає труднощів, які, не в останню чергу, пов'язані із певною пасивністю населення. Наприклад, пропозиція щодо ініціювання добровільного об'єднання територіальних громад виноситься на громадське обговорення, що проводиться протягом 30 днів із дня надходження такої пропозиції (ч. 3 ст. 5 Закону України «Про добровільне об’єднання територіальних громад»). Однак сучасні реалії переконливо свідчать про те, що деякі громади пасивно та навіть, до певної міри, відсторонено, реагують на участь у громадських обговореннях із зазначеного питання. За свідченням О.В. Ольшанського, «у м. Сєвєродонецьк Луганської обл., незважаючи на інформування населення через ЗМІ, Інтернет-ресурси, за час обговорення не надійшло до органів місцевого самоврядування жодної пропозиції від членів територіальної громади стосовно об'єднання територіальних прилеглих громад. Громада пасивно сприйняла можливість такого об'єднання» ${ }^{11}$. На жаль, зазначений дослідником випадок $є$ не тільки непоодиноким, а й починає набувати ознак систематичності, що зумовлює, на нашу думку, необхідність впровадження державою додаткових методів стимулювання територіальних громад, які досі не об'єднались в ОТГ або не приєднались до вже існуючої ОТГ, скористатись своїм правом.

Необхідність застосування комплексного підходу до визначення ОТГ слід аргументувати тим, що виключно такий підхід здатний повністю розкрити сутність ОТГ. Об'єднаною територіальною громадою є спроможна соціально-економічна спільнота із самостійно сформованими органами місцевого самоврядування, інтегрована локально, територіально, економічно і фінансово, здатна на основі різнорівневих зв'язків між іiі елементами забезпечити функціонування й розвиток інфраструктури та зростання суспільного добробуту. Слід підкреслити, що наведене авторське визначення є одним із найбільш повних у сучасній юридичній науці, проте певне застереження викликає звернення до такого підходу як до комплексного. Можливим було б припустити, що запропонований авторкою підхід, все ж таки, тяжіє до економічного, і підсилився б у разі уточнення визначення з урахуванням соціологічного підходу, згідно з яким громада розглядається як соціальна система, що характеризується тісними взаємозв'язками між членами даної системи і між системами, включаючи як горизонтальні, так і вертикальні зв'язки ${ }^{12}$. На розвиток запропонованого підходу слід зазначити, що право територіальних громад на об'єднання дозволяє також говорити про зростання рівня інвестиційної привабливості новоутворених адміністративно-територіальних одиниць, можливості збільшення надходжень до бюджету (як державного, так і місцевого), а також про підвищення рівня життя жителів ОТГ, що досягається, в тому числі, створенням робочих місць, збільшенням можливостей доступу до адміністративних, медичних, освітніх та інших послуг.

Висновки. Підсумовуючи наведене вище, видається можливим запропонувати авторське визначення ОТГ. Об'єднана територіальна громада є союзом суміжних територіальних громад сіл, селищ, міст, заснованим з метою посилення їх спроможності на засадах конституційності, законності, добровільності, повсюдності, економічної ефективності, прозорості та відкритості, відповідальності й державної підтримки. 
${ }^{1}$ Баймуратов М.О. Територіальна громада: на перехресті впливу локальних і глобальних чинників. Вісник Запорізького національного університету. Юридичні науки. 2016. № 3. С. 72-78.

2 Концепція реформування місцевого самоврядування та територіальної організації влади в Україні : схвалена розпорядженням Кабінету Міністрів України від 01 квітня 2014 р. № 333-p. URL: https://zakon.rada.gov.ua/laws/show/333-2014-p (дата звернення: 09.10.2019).

3 Баймуратов М.О. Територіальна громада у національному та міжнародному вимірах. Вісник Маріупольського державного університету. Серія : Право. 2017. Вип. 13. С. 121-132.

4 Спасів Н.Я. Об'єднана територіальна громада як новітній суб'єкт місцевого самоврядування: наукове пізнання. Науковий вісник Херсонського державного університету. Сер. : Економічні науки. 2019. Вип. 33. С. $209-211$.

5 Переверзєва А.В. Критеріальні ознаки формування об'єднаних територіальних громад: національні особливості та зарубіжний досвід. Глобальні та національні проблеми економіки. 2018. Вип. 22. С. 216-220.

6 Про добровільне об’єднання територіальних громад : Закон України від 05 лютого 2015 р. № 157-VIII. URL: https://zakon. rada.gov.ua/laws/show/157-19 (дата звернення: 09.10.2019).

7 Енциклопедичний словник з державного управління / уклад. : Ю.П. Сурмін, В.Д. Бакуменко, А.М. Михненко та ін.; за ред. Ю.В. Ковбасюка, В.П. Трощинського, Ю.П. Сурміна. Київ: НАДУ, 2010. 820 с.

8 Ковальчук Ю.М. Щодо поняття об'єднаної територіальної громади як елемента правового регулювання. Науковий вісник Міжнародного гуманітарного університету. Сер. : Юриспруденція. 2017. № 29. Т. 1. С. 87-90.

9 Планування та управління фінансовими ресурсами територіальної громади : навч. посіб. / О. Кириленко, Б. Малиняк, В. Письменний, В. Русін / Асоціація міст України. Київ: ТОВ «ПІДПРИСМСТВО «ВІ ЕН ЕЙ», 2015. 396 с.

10 Голинська О.В. Добровільне об'єднання територіальних громад: чинники спротиву, об'єктивні позиції та переваги. Актуальні проблеми державного управління. 2015. Вип 3 (спец. вип.). С. 98-104.

11 Ольшанський О.В. Об'єднання територіальних громад як механізм забезпечення їх ресурсної спроможності. Актуальні проблеми державного управління. 2015. № 2. С. 92-99.

12 Муркович Л. Територіальна громада як суб'єкт місцевого самоврядування в Україні: теоретичні аспекти. URL: http://www.dridu.dp.ua/vidavnictvo/ 2010/2010_02(5)/10mliuta.pdf (дата звернення: 09.10.2019).

\section{References:}

Baimuratov M.O. (2016). Terytorialna hromada: na perekhresti vplyvu lokalnykh i hlobalnykh chynnykiv. Visnyk Zaporizkoho natsionalnoho universytetu. Yurydychni nauky. 3, 72-78 [in Ukrainian].

Kontseptsiia reformuvannia mistsevoho samovriaduvannia ta terytorialnoi orhanizatsii vlady v Ukraini : skhvalena rozporiadzhenniam Kabinetu Ministriv Ukrainy vid 01.04.2014 r. № 333-r. URL: https://zakon.rada.gov.ua/ laws/show/333-2014-r (data zvernennia: 09.10.2019) [in Ukrainian].

Baimuratov M.O. (2017). Terytorialna hromada u natsionalnomu ta mizhnarodnomu vymirakh. Visnyk Mariupolskoho derzhavnoho universytetu. Seriia : Pravo. 13, 121-132 [in Ukrainian].

Spasiv N.Y. (2019). Obiednana terytorialna hromada yak novitnii subiekt mistsevoho samovriaduvannia: naukove piznannia. Naukovyi visnyk Khersonskoho derzhavnoho universytetu. Ser. : Ekonomichni nauky. 33, 209-211 [in Ukrainian].

Pereverzieva A.V. (2018). Kryterialni oznaky formuvannia obiednanykh terytorialnykh hromad: natsionalni osoblyvosti ta zarubizhnyi dosvid. Hlobalni ta natsionalni problemy ekonomiky. 22, 216-220 [in Ukrainian].

Pro dobrovilne obiednannia terytorialnykh hromad : Zakon Ukrainy vid 05.02.2015 r. № 157-VIII. URL: https://zakon.rada.gov. ua/laws/show/157-19 (data zvernennia: 09.10.2019) [in Ukrainian].

Saienko P.O. (2016). Teoretychni zasady formuvannia stratehii rozvytku obiednanoi terytorialnoi hromady. Ekonomika i suspilstvo. 7, 594-598 [in Ukrainian].

Entsyklopedychnyi slovnyk z derzhavnoho upravlinnia / uklad. : Y.P. Surmin, V.D. Bakumenko, A.M. Mykhnenko ta in.; za red. Y.V. Kovbasiuka, V.P. Troshchynskoho, Y.P. Surmina. K. : NADU, 2010 [in Ukrainian].

Kovalchuk Y.M. (2017). Shchodo poniattia obiednanoi terytorialnoi hromady yak elementa pravovoho rehuliuvannia. Naukovyi visnyk Mizhnarodnoho humanitarnoho universytetu. Ser : Yurysprudentsiia. 29, 1, 87-90 [in Ukrainian].

Kyrylenko, O., Malyniak, B., Pysmennyi, V., Rusin, V. (2015). Planuvannia ta upravlinnia finansovymy resursamy terytorialnoi hromady: navch. posib. Asotsiatsiia mist Ukrainy. K., TOV «PIDPRYIeMSTVO «VI EN EI» [in Ukrainian].

Holynska O.V. (2015). Dobrovilne obiednannia terytorialnykh hromad: chynnyky sprotyvu, obiektyvni pozytsii ta perevahy. Aktualni problemy derzhavnoho upravlinnia. 3, 98-104 [in Ukrainian].

Olshanskyi O.V. (2015). Obiednannia terytorialnykh hromad yak mekhanizm zabezpechennia yikh resursnoi spromozhnosti. Aktualni problemy derzhavnoho upravlinnia. 2, 92-99 [in Ukrainian].

Murkovych L. Terytorialna hromada yak subiekt mistsevoho samovriaduvannia v Ukraini: teoretychni aspekty. URL: http://www.dridu.dp.ua /vidavnictvo/2010/2010_02(5)/10mliuta.pdf (data zvernennia: 09.10.2019) [in Ukrainian].

\section{Резюме}

\section{Гайдар М.Є. До питання поняття об'єднаної територіальної громади в Україні.}

У статті зосереджена увага на тому, що модернізаційні процеси, які мають місце в нашій державі, спрямовані передусім на реформування системи місцевого самоврядування, на закріплення статусу територіальних громад основним суб'єктом місцевої демократії. Останні дослідження проблематики об'єднання територіальних громад свідчать про те, що на сучасному етапі реформування виникає низка питань, пов'язаних із конституційним регулюванням процесу об'єднання територіальних громад в Україні. Зокрема, донині законодавцем не запропоновано визначення об'єднаних територіальних громад, а вчені, які розглядають ОТГ, здебільшого фокусуються висвітленні окремих ключових проблемних аспектів їх утворення та діяльності. У статті проводиться аналіз здобутків вчених із дослідження поняття об'єднаної територіальної громади в Україні, а також пропонується авторське визначення об'єднаної територіальної громади.

Ключові слова: місцеве самоврядування, реформа, територіальна громада, об'єднана територіальна громада, поняття об’єднаної територіальної громади, децентралізація. 


\section{Резюме}

Гайдар М.Е. К вопросу понятия объединенной территориальной общины в Украине.

В статье сосредоточено внимание на том, что модернизационные процессы, которые имеют место в нашем государстве, направлены, прежде всего, на реформирование системы местного самоуправления, на закрепление статуса территориальных общин основным субъектом местной демократии. Последние исследования проблематики объединения территориальных общин свидетельствуют о том, что на современном этапе реформирования возникает ряд вопросов, связанных с конституционным регулированием процесса объединения территориальных общин в Украине. В частности, до сих пор законодателем не предложено определение объединенных территориальных общин, а ученые, рассматривающие объединенные территориальные общины, в основном фокусируются освещении отдельных ключевых проблемных аспектов их образования и деятельности. В статье проводится анализ достижений ученых по исследованию понятия объединенной территориальной общины в Украине, а также предлагается авторское определение объединенной территориальной общины.

Ключевые слова: местное самоуправление, реформа, территориальная община, объединенная территориальная община, понятие объединенной территориальной общины, децентрализация.

\section{Summary}

Maria Gaidar. On the concept of a united territorial community in Ukraine.

The article focuses on the fact that the modernization processes, which take place in our state, are aimed, first of all, at reforming the system of local self-government, at fixing the status of territorial communities as the main subject of local democracy. The Constitution of Ukraine recognizes and guarantees local self-government. Local self-government is recognized as a right of a territorial community - residents of a village or voluntary association in a rural community of residents of several villages, towns and cities - to independently resolve issues of local importance within the Constitution and laws of Ukraine. Recent researches on the subject of united territorial communities indicate that at the present stage of reformation there are a number of issues related to the constitutional regulation of the process of unification of territorial communities in Ukraine. The term «uniting of the territorial communities» is permanently featured in most of the regulatory acts, which have been adopted in connection with the implementation of the decentralization reform in Ukraine. However, in particular, the legislator has not yet proposed a definition of united territorial communities, and scientists considering united territorial communities mainly focus on highlighting of certain key problematic aspects of their formation and activities. The article analyzes the achievements of scientists to study the concept of a united territorial community in Ukraine; various terms proposed by the authors are analyzed. The author's definition of a united territorial community, based on the various researches, is proposed.

It is stated that the united territorial community is an alliance of neighboring territorial communities of villages, settlements, cities, established to enhance their capacity on the basis of constitutionality, legality, voluntariness, ubiquity, economic efficiency, transparency and openness, accountability and state support.

Key words: local self-government; reform; territorial community; united territorial community; the concept of a united territorial community; decentralization. 